\title{
Intramedullary Neurenteric Cyst of the Conus Medullaris without Associated Spinal Malformation: A Case Report and Review of the Literature
}

\author{
İliskili Spinal Malformasyon Olmadan Konus Medullarisin \\ Intramedüller Nöroenterik Kisti: Bir Olgu Sunumu ve Literatürün \\ Gözden Geçirilmesi
}

\author{
Behrouz SADEGHI-HARIRI, Mahmoud Reza KHALATBARI, Hajar HASSANI, Behrouz TAHERI, \\ Kazem ABBASSIOUN \\ Arad Hospital, Department of Neurosurgery, Tehran, Islamic Republic of Iran
}

Correspondence address: Mahmoud Reza KHALATBARI / E-mail: mrkhalatbari@hotmail.com

\begin{abstract}
Spinal neurenteric (NE) cysts are rare congenital anomalies that may occur either alone or in the context of a complex malformative disorder. They are usually intradural-extramedullary lesions. Intramedullary NE cysts not associated with other congenital anomalies are very rare and only a few cases have been reported in the conus medullaris region. Intramedullary neurenteric cysts not associated with other spinal anomalies are very rare especially in the conus medullaris region. MRI is useful to define the cyst and the osseous anomalies associated with this lesion. The goal of treatment of an intramedullary neurenteric cyst is total excision at the first operation, if possible. Life-long follow-up with annual MRI is recommended due to the risk of cyst recurrence. We report an intramedullary NE cyst of the conus medullaris without associated malformation and the relevant literature is briefly reviewed.
\end{abstract}

KEYWORDS: Neurenteric cyst, Conus medullaris, Intramedullary lesion

öz

Spinal nöroenterik (NE) kistler tek başına veya kompleks bir malformasyon bozukluğu kapsamında görülebilen nadir konjenital bozukluklardır. Genellikle intradural-ekstramedüller lezyonlardır. Başka konjenital anomalilerle ilişkili olmayan intramedüller NE kistleri çok nadirdir ve konus medullaris bölgesinde sadece birkaç vaka bildirilmiştir. Spinal anomalilerle ilişkili olmayan intramedüller nöroenterik kistler özellikle konus medüllaris bölgesinde çok nadirdir. Kisti ve lezyonla ilişkili osseöz anomalileri tanımlamak için MRG faydalıdır. Bir intramedüller nöroenterik kist tedavisinde amaç mümkünse ilk ameliyatta total eksizyondur. Kist reküransı riski nedeniyle yılda bir MRG ile ömür boyu takip önerilir. İlişkili bir malformasyon olmadan konus medullaris intramedüller NE kisti bildiriyor ve ilgili literatürü kısaca gözden geçiriyoruz.

ANAHTAR SÖZCÜKLER: Nöroenterik kist, Konus medullaris, İntramedüller lezyon

\section{INTRODUCTION}

Neurenteric (NE) cysts are rare congenital lesions of foregut origin which occur most commonly in the cervical and cervico-thoracic spinal segments. They are usually intradural extramedullary and are lined by columnar epithelium of the intestinal type $(1,17)$.

Intramedullary NE cysts of the spinal cord are rare lesions and comprise less than $5 \%$ of all spinal NE cysts $(9,11,13)$. Isolated intramedullary NE cysts of the spinal cord not associated with bone or soft tissue malformations are very rare and only 33 cases have been reported in the literature (11).

Isolated intramedullary NE cysts of the conus medullaris are extremely rare and only 6 cases have been reported in the literature $(5,8,16-18)$. We intend to report a case of isolated intramedullary NE cyst of the conus medullaris with longterm follow-up and review of the pertinent literature.

\section{CASE REPORT}

A 40-year-old man presented with a history of low back pain for 10 years. During this period, he suffered from weakness of his left lower limb. He underwent T12-L1 posterior laminectomy at another medical center 8 years before presentation at our center, but the operation did not improve the patient's symptoms. No lesion had been diagnosed at the first operation. His low back pain and left lower limb weakness increased postoperatively. Three months prior to the second admission, he suffered left L5 radicular pain and intermittent urinary urgency and right lower limb paresis. His medical history was otherwise normal. 
Upon admission, neurological examination of the left leg revealed complete sensory loss with severe motor deficit (motor strength in the distal part was $1 / 5$ and in the proximal part was 3/5). Motor strength of the right leg was $4 / 5$.

Reviewing the patient's radiographs related to eight years earlier revealed no abnormality of the thoracolumbar spine. MR imaging study revealed a non-enhancing intramedullary cyst of the spinal cord at the $L_{1}$ and $L_{2}$ vertebral bodies, brightly hyperintense to cerebrospinal fluid (CSF) on $\mathrm{T}_{1}$-weighted sequence and isointense to CSF on $\mathrm{T}_{2}$-weighted sequence (Figure $1 A, B$ ). One year after the first unsuccessful operation, spinal MRI showed that the cyst was slightly hyperintense compared to CSF and slightly hypointense relative to cord on $\mathrm{T}_{1}$-weighted and isointense compared to CSF on $\mathrm{T}_{2}$-weighted
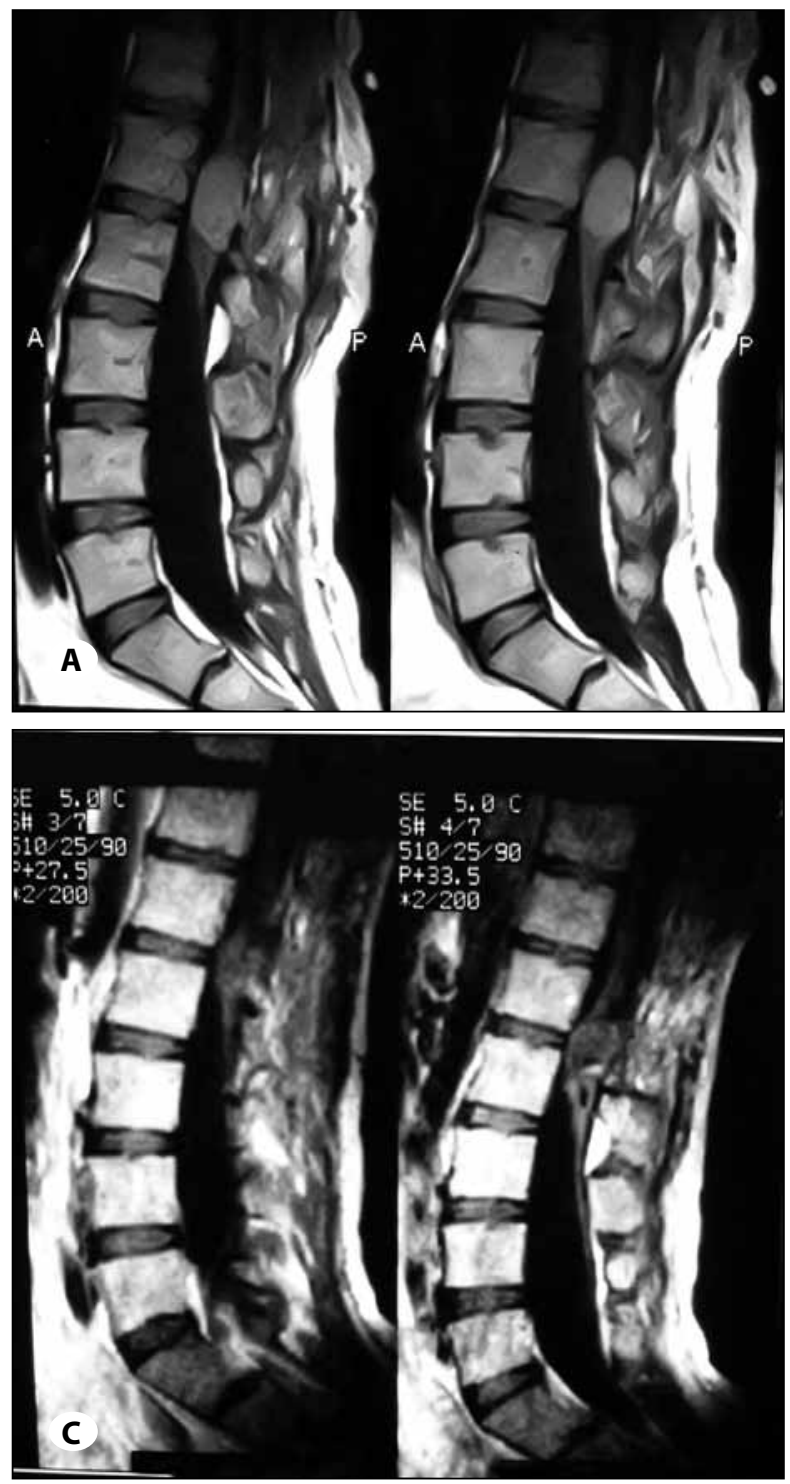

images with no enhancement (Figure 1C). Four years later, MRI showed that the cyst was hyperintense relative to CSF and spinal cord on $T_{1}$ weighted and isointense to CSF on T2weighted images without enhancement (Figure 1D).

One week before admission to our hospital, MRI demonstrated an intramedullary lesion in the conus medullaris dorsal to $L_{1}$ and $L_{2}$ vertebral bodies which resulted in the conus medullaris expansion. The cyst showed markedly high intensity on $\mathrm{T}_{1}$ weighted sequence and was isointense to CSF on $\mathrm{T}_{2}$-weighted images, and enhanced after gadolinium injection (Figure 2).

At operation, the conus medullaris was swollen. A myelotomy was performed that revealed a thin wall cyst containing creamy jelly-like contents. The cyst appeared to be encapsulated with
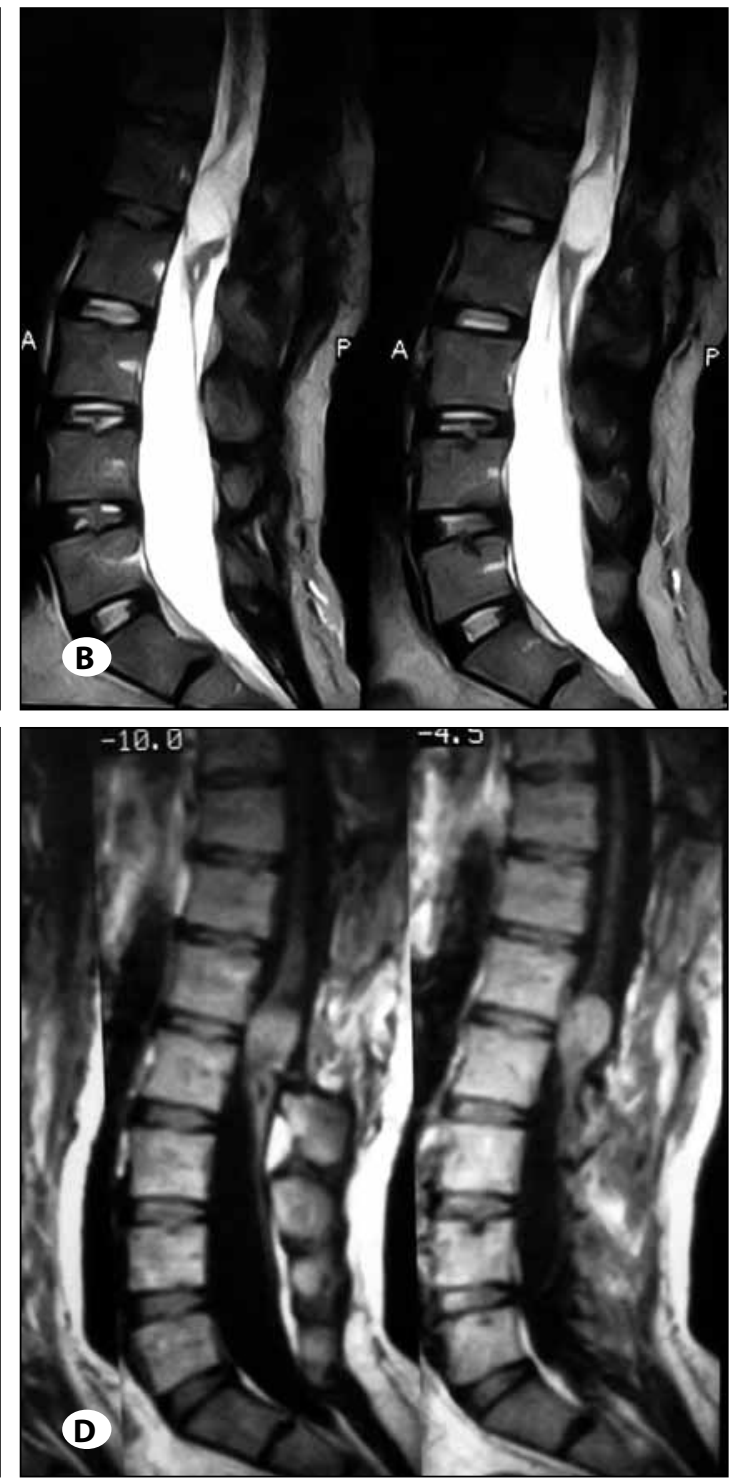

Figure 1: A) T1-weighted non-contrast MRI demonstrates a hyperintense intramedullary neurenteric cyst. B) T2-weighted MRI showing isointense intramedullary conus medullaris neurenteric cyst. C) T1-weighted MRI shows slightly hyperintense intramedullary conus neurenteric cyst one year after the first operation. D) T1-weighted non-contrast MRI of lumbosacral spine demonstrates a hyperintense intramedullary neurenteric cyst of the conus medullaris. 


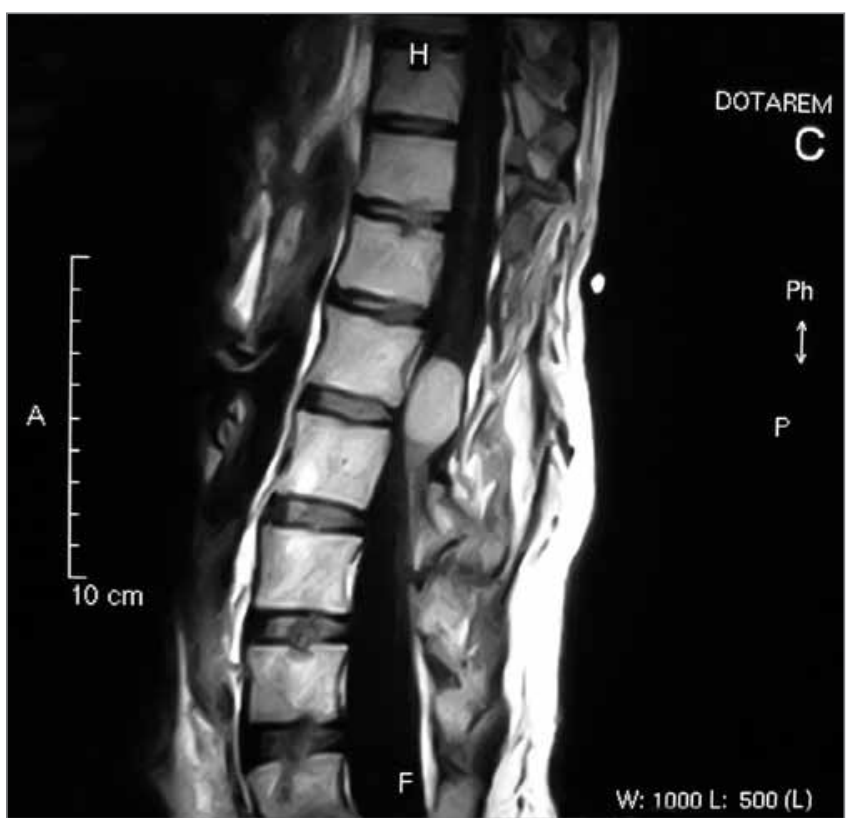

Figure 2: T1-weighted GD-MRI shows intramedullary neurenteric cyst of the conus medullaris with enhancement.

a clear plane of dissection between the cyst and neural tissue. After aspiration of the content, complete removal of the cyst wall was achieved.

Pathological examination revealed a cyst wall lined by a simple columnar to cuboidal epithelium. The supporting stroma consisted of a vascularized fibrous tissue with focal aggregate of ganglion cells. The final diagnosis was NE cyst.

The patient's postoperative course was uneventful. At followup, he was ambulatory and motor power improved markedly.

\section{DISCUSSION}

NE cysts are rare congenital lesions of endodermal origin (1, $12,13,17,18)$. They are lined with columnar and/or respiratory epithelium $(3,7,17)$ and occur predominantly in intraspinal location, usually ventral to the spinal cord, $(3,4,7,8,11,12$, $13,18,20)$ and rarely dorsal to the cord $(3,20)$. They are usually single, occurring primarily in the lower cervical and upper thoracic regions $(4,7,10,12,14,17-19,22)$. Rarely, NE cysts occur in the lumbar spine $(9,12)$. Almost $95 \%$ of the spinal $\mathrm{NE}$ cysts are intradural extramedullary and fewer than $5 \%$ are intramedullary $(6,9,11,14,18,23)$. As was observed in the presented case, intramedullary NE cysts are usually located in the extremes of the spinal cord and this may be due to the late closure of the neural tube at these levels $(8,11,14,17)$.

At least $50 \%$ of spinal NE cysts are associated with vertebral anomalies such as spina bifida occulta, hemivertebrae, Klippel-Feil syndrome, spinal lipoma, and syringomyelia $(1,4$, 19). These vertebral defects are typically seen in the cervical or upper thoracic spine, $(3,22)$ though these associated abnormalities may be absent in adults as in the present case.
Intraspinal NE cysts represent 0.7 to $1.3 \%$ of all spinal tumors $(2,8,9,11,18,20)$. NE cysts occur in men 1.5 to 3 times as often as in women $(2,9,11,18,20)$. Spinal NE cysts occur in all age groups, but they most commonly present at either early in life $(5,7)$ or in the second and third decades of life $(2,9$, $11,17,18,20)$. The precise etiology of NE cysts is unknown. Several hypotheses have been postulated in order to explain the pathogenesis of these lesions. These include (1) ectopic abnormal accessory NE canals cephalad to the coccygeal tip $(7,8,10,18,20,21)(2)$ disorder of notochord formation (splitnotochord theory) $(2,7,8,10,11,20,21)$ (3) focal adhesions between the endoderm and ectoderm within the primitive streak (endoderm-ectoderm adhesion theory) (8, 10, 12, 21). The most commonly accepted explanation is the split notochord theory $(2,11,20)$.

NE cysts have a variety of presentations depending on the age of patient, size and location of the lesion $(3,7,10,20)$. In most cases, as was observed in our patient, spinal pain is the first and most frequent symptom $(6,8,9,17,23)$. Pain can either be local or radicular $(6,8,10)$ and is mainly due to spinal cord and nerve root compression $(4,7,8,20)$. Some patients with NE cysts present with intermittent symptoms like multiple sclerosis $(3,7,10,11,17,18,20)$. Intermittent symptoms are probably due to a thin-walled cyst of the spinal canal $(8,9$, $11,17,18,20)$ that gradually increase in size by secretion from the cyst wall and osmotic retention of CSF, and decrease in size by small ruptures in to the subarachnoid space $(8,9,11$, $12,18-20)$ and re-absorption of mucin by the cyst wall $(8,9$, $11,18,20)$. Meningitis, either chemical or bacterial, is a rare presentation of NE cysts which is more common in newborns and infants $(4,7,8,11,14,20)$. NE cysts may also present as a psychogenic disorder $(8,11)$ or hydrocephalus $(7,8,11)$.

Adults tend to present with signs of spinal cord compression which may follow trivial trauma $(3,6)$. In some cases, neurological signs can be of acute onset due to spontaneous hemorrhage into the cyst $(6,7)$ or an increase in the size of the cyst as the result of an accumulation of intracystic fluid $(3,6,7,12)$.

The radiographic evaluation of an intraspinal NE cyst includes plain spinal $x$-ray and magnetic resonance imaging (8, 10). Plain $x$-rays are useful in the detection of spinal bony anomalies associated with NE cysts such as widening of the spinal canal, partial fusion, hemivertebrae, anterior and posterior spina bifida, and scoliosis $(8,21)$.

Because of its ability to image in the axial, coronal, and sagittal planes and the availability of gadolinium as an enhancing agent, MRI has recently supplanted CT myelography $(8,11$, 20). MRI provides a complete, non-invasive assessment of the bony abnormality, the exact location and extent of the cyst, and the degree of spinal cord or nerve root compression associated with a NE cyst $(6,8,11,12,18-21)$. The signal intensity of NE cysts varies depending on the protein content of the cyst fluid or hemorrhage within the cyst $(8,20)$. They are usually isointense or slightly hyperintense relative to CSF on $\mathrm{T}_{1}$-weighted $\mathrm{MR}$ images and isointense to hyperintense 
relative to CSF on $T_{2}$-weighted $M R$ images $(6,8,11,19)$. NE cysts are iso-intense to CSF on T1- and T2-weighted images if the cyst contents are clear like $\operatorname{CSF}(4,20)$. Occasionally, homogenous very bright signal intensity on $\mathrm{T}_{1}$-weighted MRI and/or very low signal intensity on $\mathrm{T}_{2}$ weighted $\mathrm{MRI}$ may be seen, which are thought to correlate with protein content or hemorrhage within the cysts $(6,8,20,23)$. A mural nodule has been described in one case (13). Calcification has been reported in some patients (23). Rim enhancement is rare (11).

In the presented case, the cyst content was creamy and its signal appeared very bright on T1-weighted sequence and iso-signal relative to CSF on T2-weighted images. The cyst enhanced after gadolinium injection. We think that laminectomy and dural opening at the first operation caused cord and cyst decompression and changes in the CSF flow in thoracolumbar region. This led to CSF penetration through the cyst wall into the cyst and the cyst content concentration decreased, which was responsible for the reduced cyst density on imaging. A few years later, local arachnoiditis at the site of operation caused adhesion around the cyst wall and changed the CSF flow, and secretion by the cells of the cyst wall caused an increase in the contents of the cyst. This led to increased density of the lesion on MRI.

The gross appearance of NE cysts may vary from thin to thickwalled, with color being grayish white or creamy (18).

Pathologically, the most common finding is a thin wall, lined by a layer of ciliated or non-ciliated cuboidal or columnar epithelium, lying on a basement membrane and supported by a connective tissue wall of varying vascularity $(7,8,18,23)$. The majority of isolated intramedullary NE cysts are located in the thoracic region and occur almost equally in women and men (23). The age of presentation ranges from 3 weeks to 68 years old. Pain is the most common presenting symptom of isolated spinal NE cyst (23). Isolated intramedullary NE cysts usually have iso- to hypo-intense $\mathrm{T} 1$-weighted appearance

Table I: Summary of Reports Regarding Isolated Intramedullary Neurenteric Cyst of the Conus Medullaris Published in the Literature

\begin{tabular}{|c|c|c|c|c|c|c|c|c|}
\hline $\begin{array}{l}\text { Authors \& } \\
\text { Year }\end{array}$ & $\begin{array}{l}\text { Age } \\
\text { (yrs), } \\
\text { sex }\end{array}$ & $\begin{array}{l}\text { History \& } \\
\text { examination }\end{array}$ & Imaging & $\begin{array}{c}\text { Cyst } \\
\text { location }\end{array}$ & Operation & $\begin{array}{l}\text { Intraope- } \\
\text { rative } \\
\text { finding }\end{array}$ & Outcome & Recurrence \\
\hline $\begin{array}{l}\text { Rewcastle et al. } \\
\text { [16] } 1964\end{array}$ & $34, F$ & $\begin{array}{l}\text { LBP, LE paresis, } \\
\text { DS, UI, BI }\end{array}$ & Normal x-ray & T7-L2 & $\begin{array}{l}\text { Subtotal } \\
\text { resection }\end{array}$ & NR & $\begin{array}{l}\text { UI,BI } \\
\text { improved, } \\
\text { worse } \\
\text { paresis }\end{array}$ & No \\
\hline $\begin{array}{l}\text { Fortuna et al. } \\
\text { [5] } 1983\end{array}$ & $47, F$ & LE paresis, UI & Normal x-ray & T11-L1 & $\begin{array}{l}\text { Subtotal } \\
\text { resection }\end{array}$ & NR & Improved & No \\
\hline $\begin{array}{l}\text { Rivierez et al. } \\
{[17], 1997}\end{array}$ & $46, F$ & LBP, LE paresis & $\begin{array}{l}\text { Normal x-ray, MRI: IM } \\
\text { cyst, wall enhancing, } \\
\text { T1:isointense } \\
\text { T2:hypointense }\end{array}$ & L1-L2 & $\begin{array}{l}\text { Cysto- } \\
\text { subarachnoid } \\
\text { shunt }\end{array}$ & $\begin{array}{l}\text { Clear } \\
\text { fluid }\end{array}$ & worse & Yes \\
\hline $\begin{array}{l}\text { Rotondo et al. } \\
\text { [17] } 2005\end{array}$ & $52, F$ & LBP, Dysuria & $\begin{array}{l}\text { Normal x-ray, } \\
\text { Normal CT scan, } \\
\text { MRI:T1 hypointense, } \\
\text { T2 Hyperintense, } \\
\text { Nonenhancing }\end{array}$ & T12-L1 & Total & $\begin{array}{l}\text { Clear } \\
\text { fluid }\end{array}$ & Improved & No \\
\hline $\begin{array}{l}\text { Rotondo et al. } \\
\text { [18] } 2005\end{array}$ & $61, F$ & $\begin{array}{l}\text { LBP, LE paresis \& } \\
\text { paresthsia }\end{array}$ & $\begin{array}{l}\text { Normal x-ray, Nornal } \\
\text { CT scan, MRI:T1 } \\
\text { Hypointense, T2 } \\
\text { Hyperintense }\end{array}$ & T12-L1 & Total & $\begin{array}{l}\text { Thick } \\
\text { yellow } \\
\text { fluid }\end{array}$ & Improved & No \\
\hline Park et al. [14] & $6, F$ & $\begin{array}{l}\text { LBP, gait } \\
\text { disturbance }\end{array}$ & $\begin{array}{l}\text { Normal x-ray, MRI: } \\
\text { IM cyst, T1 slightly } \\
\text { hyperintense, T2 } \\
\text { Hypointense }\end{array}$ & L1-L2 & $\begin{array}{l}\text { Subtotal } \\
\text { resection, }\end{array}$ & $\begin{array}{l}\text { Milky } \\
\text { Fluid }\end{array}$ & Improved & No \\
\hline Present case & $40, M$ & LBP, LE paresis & $\begin{array}{l}\text { Normal x-ray, MRI: IM } \\
\text { cyst, Wall enhancing, } \\
\text { T1: brightly } \\
\text { Hyperintense, T2: } \\
\text { isointense }\end{array}$ & L1-L2 & Total & $\begin{array}{l}\text { Creamy } \\
\text { Jelly-like } \\
\text { fluid }\end{array}$ & Improved & No \\
\hline
\end{tabular}

Abbreviations: $\mathbf{F}=$ Female, $\boldsymbol{M}=$ Male, $\mathbf{L B P}=$ Low back pain, $\mathbf{L E}=$ Lower extremities, $\mathbf{I} \boldsymbol{M}=$ Intramedullary, $\mathbf{N R}=$ Not reported, $\boldsymbol{U}=$ Urinary incontinence, $\mathbf{B} \mathbf{I}=$ Bowel incontinence, $\mathbf{D S}=$ Dysuria. 
and are rarely enhanced (23). In one case, T1-weighted MRI showed hyperintensity.

Isolated intramedullary NE cysts are very rare and only 33 cases have been reported in the literature of which only 19 cases were evaluated by MRI (11). An isolated intramedullary NE cyst of the conus medullaris is an extremely rare lesion and only seven cases have been reported (including the present case) (Table I).

The natural history of untreated intraspinal NE cyst is unfavorable $(18,22)$. The proper treatment of NE cysts is complete surgical removal $(7,9,10-12,19,22)$. In an intramedullary NE cyst, complete excision is often difficult due to infiltration and/or firm adhesion of lesion to the neural tissue $(8,9,11,12,18,19)$. Therefore, overaggressive resection of an intramedullary NE cyst is dangerous and should be avoided $(2,3,8,9,11,18)$. However, if the cyst is very adherent to the spinal cord or if a clear dissection plane cannot be found, a subtotal resection is sufficient $(2,3,8,9,11,18)$. Subtotal resection (cyst aspiration, fenestration, partial resection) has yielded good immediate results but has higher recurrence rates and should be avoided, if possible $(8,9,11,14,15,18)$. Associated anomalies such as diastematomyelia, lipoma, tethered spinal cord, mediastinal mass and abdominal mass will require special treatment (10).

NE cysts can recur despite long-term symptomatic relief and hence a life-long follow-up with annual MRI is warranted (2, $11,12,17,19,20)$.

\section{CONCLUSION}

A NE cyst is a rare congenital anomaly that develops in early gestation. It has a variety of presentations, depending on the size and location of the lesion and age of the patient. Intramedullary NE cysts not associated with other congenital anomalies are very rare, especially in the conus medullaris region. $\mathrm{MRI}$ and $\mathrm{CT}$ scan are necessary to define the cyst and the osseous and vascular anomalies associated with this lesion. The goal of treatment of an intramedullary NE cyst is total excision at the first operation, if possible. Lifelong follow-up with annual MRI is recommended due to the recurrence risk.

\section{REFERENCES}

1. Agnoli $A L$, laun $A$, Schonmayr R: Enterogenous intraspinal cysts. J Neurosurg 61:834-840, 1984

2. Agrawal D, Suri A, Mahapatra AK, Sharma MC: Intramedullary neurenteric cyst presenting as infantile paraplegia: A case and review. Pediatr Neurosurg 37:93-96, 2002

3. Chang IC: Thoracic neurenteric cyst in a middle aged adult presenting with Brown-Sequard syndrome. Spine 28: E515-E518, 2003

4. de Oliveira RS, Cinalli G, Roujeau T, Sainte-Rose C, Pierre-Kahn A, Zerah M: Neurenteric cyst in children: 16 consecutive cases and review of the literature. J Neurosurg 103:512-523, 2005

5. Fortuna A, Mercuri S: Intradural spinal cyst. Acta Neurochir 68: 289-314, 1983
6. Hicdonmez T, Steinbok P: Spontaneous hemorrhage into spinal neurenteric cyst. Childs Nerv Syst 20:438-442, 2004

7. Kumar R, Jain R, Rao KM, Hussain N: Intraspinal neurenteric cyst-report of three paediatric cases. Childs Nerv Syst 17: 584-588, 2001

8. Kumar R, Nayak SR: Unusual neuroenteric cysts: Diagnosis and management. Pediatr Neurosurg 37:321-330, 2002

9. Lippman CR, Arginteanu M, Purohit D, Naidich TP, Vamins MB: Intramedullary neurenteric cysts of the spine. Case report and review of the literature. J Neurosurg 94:305-309, 2001

10. Menezes A, Traynelis VC: Spinal neurenteric cyst in the magnetic resonance imaging era. Neurosurgery 58:97-105, 2006

11. Muzumdar D, Bhatt $Y$, Sheth J: Intramedullary cervical Neurenteric cyst mimicking an abscess. Pediatr Neurosurg 44: 55-61, 2008

12. Oyama H, Ikeda A, Inoue S, Nakamura S, Nishimura Y, Shibuya M: Multiple neurenteric cysts in the posterior fossa and cervical spinal canal. Case report. Neurol Med Chir (Tokyo) 44: 146-149, 2004

13. Paolini S, Ciappetta $P$, Domenicucci $M$, Guiducci $A$ : Intramedullary neurenteric cyst with a false mural nodule: Case report. Neurosurgery 52:243- 246, 2003

14. Park YB, Kim SH, Kim SW: An intramedullary neurenteric cyst in the conus medullaris with recurrent meningitis. J Korean Neurosurg Soc 41:130-133, 2007

15. Piramoon AM, Abbassioun K: Mediastinal enterogenic cyst with spinal cord compression. J Pediatr Surg 9:543-545, 1974

16. Rewcastle N, Francoeur J: Teratomatous cyst of the spinal canal. Arch Neurol 91-99, 1964

17. Riviérez $M$, Buisson $G$, Kujas $M$, Ridarch A, Mignon $E$, Jouannelle $A$, Rene-Corail P: Intramedullary neurenteric cyst without any associated malformation. One case evaluated by RMI and electron microscopic study. Acta Neurochir (Wien) 139: 887-890, 1997

18. Rotondo M, D'Avanzo R, Natale M, Pasqualetto $L$, Bocchetti A, Agozzino L, Scuotto A: Intramedullary neurenteric cysts of the spine. Report of three cases. J Neurosurg Spine 2: 372-376, 2005

19. Sakata $H$, Fujimura $M$, Iwasaki $M$, Tominaga T: Neurenteric cyst of the craniocervical junction in an infan. Neurol Med Chir (Tokyo) 48:86-89, 2008

20. Shenoy SN, Raja A: Spinal neurenteric cyst: Report of 4 cases and review of the literature. Pediatr Neurosurg 40:284-292, 2004

21. Singhal BS, Parekh HN, Ursekar M, Deopujari CE, Manghan DK: Intramedullary nerenteric cyst in midthoracic spine in an adult: A case report. Neurology India 49:302-304, 2001

22. Yunoki M, Hirashita K, Gohda Y, Yoshino K, Fujimato $S$, Mizobuchi K: True intraspianl neurenteric cyst in the lumbosacral region-case report. Neurol Med Chir (Tokyo) 47: 237-239, 2007

23. Ziu M, Vibhute P, Vecil GG, Henry J: Isolated spinal neurenteric cyst presenting as intramedullary calcified cystic mass on imaging studies. Case report and review of literature. Neuroradiology 52:119-123, 2010 